\title{
Analisis Pemanfaatan Limbah Ikan Menjadi Pupuk Organik Cair (Poc) Di Desa Tanah Merah Kecamatan Belitang Madang Raya Kabupaten Oku Timur
}

\author{
Hariyono \\ Sekolah Tinggi Ilmu Pertanian Belitang \\ Jln.Kampus Pertanian No.3 Belitang Kab.OKU Timur Prov.Sumatera Selatan \\ e-mail: hariyono.ss@gmail.com
}

\begin{abstract}
ABSTRAK
Tujuan dari penelitian ini adalah untuk: 1) mengetahui bagaimana kelayakan teknis pada usaha pengolahan limbah ikan menjadi pupuk organik cair (POC) di Desa Tanah Merah Kecamatan Belitang Madang Raya Kabupaten OKU Timur, 2) menganalisa potensi tingkat keuntungan pada usaha pengolahan limbah ikan menjadi pupuk organik cair (POC) di Desa Tanah Merah Kecamatan Belitang Madang Raya Kabupaten OKU Timur. Hasil penelitian menunjukkan bahwa usaha pengolahan limbah ikan menjadi pupuk organik cair di Desa Tanah Merah Kecamatan Belitang Madang Raya Kabupaten OKU Timur layak secara teknis. Usaha pengolahan limbah ikan menjadi pupuk organik cair di Desa Tanah Merah Kecamatan Belitang Madang Raya Kabupaten OKU Timur menguntungkan dengan indikator indikatornya adalah R/C Rasio sebesar 6,88 BEP Harga sebesar Rp 5.814/Botol, BEP produksi sebesar 10/Botol.
\end{abstract}

\section{Kata Kunci : Pupuk Organik Cair (POC), Limbah Ikan, Kelayakan Usahatani}

\section{PENDAHULUAN}

\section{A. Latar Belakang}

Pemanfaatan limbah ikan yang banyak dihasilkan dari kegiatan perikanan memiliki kandungan yang diharapkan dapat meningkatkan unsur hara yang dibutuhkan tanaman dalam pupuk organik. Pupuk kimia yang beredar di pasaran selain harganya mahal juga memiliki dampak buruk bagi lingkungan seperti menurunkan tingkat kesuburan tanah, sehingga timbul pemikiran untuk menggunakan pupuk organik.Penggunaan Pupuk Anorganik yang berkepanjangan menyebabkan menurunnya tingkat kesuburan tanah secara signifikan sehingga menurunkan tingkat produktifitas tanaman (Kasim et al, 2011).

Kandungan hara Nitrogen, Fosfor dan Kalium organik di dalam tubuh ikan mempunyai kelebihan bila dibandingkan dengan bahan-bahan lainnya.Tulang ikan memiliki kandungan Fosfor yang tinggi sehingga dapat dijadikan sumber utama Fosfor (Mazaya et al, 2013). Fosfor dalam tulang biasanya berbentuk Kalsium Fosfat (Ca3(PO4)2). Pupuk organik yang terbuat dari bahan baku ikan memiliki kualitas sebagai pupuk yang lebih baik bila dibandingkan dengan pupuk organik lain, apalagi jika dibandingkan dengan pupuk kompos, pupuk kandang, ataupun pupuk hijau (Anonim, 2007).

Selain limbah, salah satu bahan yang dapat dimanfaatkan dalam pembuatan pupuk organik adalah Mikro Organisme Lokal (MOL) yang merupakan bakteri hasil fermentasi dari bahan-bahan organik seperti limbah sayuran, buah-buahan, perikanan, peternakan dan lain-lain. MOL dimanfaatkan sebagai starter untuk mempercepat proses pembuatan pupuk organik. Larutan MOL mengandung unsur hara makro dan mikro serta mengandung bakteri yang berpotensi sebagai perombak bahan organik, perangsang pertumbuhan dan sebagai agen pengendali hama dan penyakit tanaman, sehingga MOL dapat digunakan sebagai pendekomposer, pupuk hayati dan pestisida (Hadinata, 2008).
Tabel 1.Standar Kandungan Pupuk Organik Cair (POC)

\begin{tabular}{|c|c|c|c|}
\hline No & PARAMETER & SATUAN & STANDAR MUTU \\
\hline 1. & C-organik & $\%(\mathrm{w} / \mathrm{v})$ & Minimum 10 \\
\hline 2. & $\begin{array}{l}\text { Hara Makro } \\
\mathrm{N}+\mathrm{P}_{2} \mathrm{O}_{5}+\mathrm{K}_{2} \mathrm{O}\end{array}$ & $\%(\mathrm{w} / \mathrm{v})$ & $2-6$ \\
\hline 3. & $\mathrm{~N}$-organik & $\%(\mathrm{w} / \mathrm{v})$ & Minimum 0,5 \\
\hline \multirow[t]{7}{*}{4.} & Hara Mikro & & \\
\hline & - Fe total & ppm & $90-900$ \\
\hline & - $\quad$ Mn total & ppm & $25-500$ \\
\hline & - $\quad \mathrm{Cu}$ total & ppm & $25-500$ \\
\hline & - $\quad$ Zn Total & ppm & $25-500$ \\
\hline & - B total & $\mathrm{ppm}$ & $12-250$ \\
\hline & - $\quad$ Mo total & $\mathrm{ppm}$ & $2-10$ \\
\hline 5. & $\mathrm{pH}$ & - & $4-9$ \\
\hline \multirow[t]{2}{*}{6.} & E.coli & cfu/ml atau MPN/ml & $<1 \times 10^{2}$ \\
\hline & Salmonella $s p$ & $\mathrm{cfu} / \mathrm{ml}$ atau $\mathrm{MPN} / \mathrm{ml}$ & $<1 \times 10^{2}$ \\
\hline \multirow[t]{7}{*}{7.} & Logam Berat & & \\
\hline & - As & ppm & Maksimum 5,0 \\
\hline & - $\quad \mathrm{Hg}$ & ppm & Maksimum 0,2 \\
\hline & - $\quad \mathrm{Pb}$ & ppm & Maksimum 5,0 \\
\hline & $-\quad \mathrm{Cd}$ & ppm & Maksimum 1,0 \\
\hline & $-\mathrm{Cr}$ & ppm & Maksimum 40 \\
\hline & - $\mathrm{Ni}$ & $\mathrm{ppm}$ & Maksimum 10 \\
\hline \multirow[t]{3}{*}{8.} & Unsur/senyawa lain & & \\
\hline & - $\mathrm{Na}$ & ppm & Maksimum 2.000 \\
\hline & $-\quad \mathrm{Cl}$ & $\mathrm{ppm}$ & Maksimum 2.000 \\
\hline
\end{tabular}

Sumber: Keputusan Rapat Kementrian Pertanian, 2019.

Pupuk organik berperan dalam memperbaiki sifat fisik, kimia, dan biologi tanah. Pemanfaatan limbah ikan juga mengurangi pencemaran lingkungan yang diakibatkan limbah hasil pengolahan ikan yang dibuang begitu saja tanpa memperhatikan dampak negatifnya terhadap lingkungan.Pemanfaatan limbah ikan menjadi pupuk organik bertujuan untuk menghasilkan pupuk yang kaya berbagai nutrien yang diperlukan tanaman, mengatasi kelangkaan pupuk, dan mendukung program pemerintah yaitu “Go Organic' (Hapsari \& Welasi, 2013).

Seiring dengan meningkatnya kesadaran masyarakat untuk hidup sehat dan kembali ke alam (back to nature) tampak semakin gencar pula usaha untuk memproduksi hasil pertanian yang aman dari residu dan bahan kimia berbahaya, yakni dengan menggunakan pupuk organik.Hal ini dapat ditandai dengan prilaku masyarakat yang sudah 
mulai memilih produk aman dari bahan-bahan kimia, misalnya beras dan sayur organik.Sayangnya harga makanan organik tersebut masih relatif tinggi.Hal itu terjadi karena ketersediaan pupuk organik yang dipakai untuk memproduksi bahan makanan organik tersebut masih sangat kurang di pasaran sehingga petani terpakasa memakai pupuk anorganik (pupuk kimia) (Patanga dan Yuliarti, 2016).

Belitang yang merupakan salah satu kecamatan di Kabupaten OKU Timur dapat dikatakan sebagai daerah rintisan pertanian organik. Petani konvensional beranggapan apabila ia melakukan budidaya secara organik ada banyak kesulitan yang akan dihadapi. Salah satu kesulitan terbesar para petani konvensional yaitu untuk memperoleh pupuk organik. Petani belum melihat potensi lokal yang ada berupa limbah pertanian yang tersedia melimpah yang dapat dikelola menjadi pupuk organik.Pentingnya mengembangkan sistem pertanian yang berwawasan lingkungan berkelanjutan dan pemanfaatan sumber daya lokal, pertanian organik menjadi salah satu pilihan yang dapat diambil.

\section{B. Rumusan Masalah}

Berdasarkan uraian diatas, maka rumusan masalah dalam penelitian ini meliputi :

1. Bagaimana kelayakan teknis pada usaha pengolahan limbah ikan menjadi pupuk organik cair (POC) di Desa Tanah Merah Kecamatan Belitang Madang Raya Kabupaten Oku Timur?

2. Berapakah potensi tingkat keuntungan pada usaha pengolahan limbah ikan menjadi pupuk organik cair (POC) di Desa Tanah Merah Kecamatan Belitang Madang Raya Kabupaten Oku Timur?

\section{Tujuan dan Kegunaan}

Bertolak dari rumusan masalah diatas, maka penelitian ini bertujuan untuk :

1. Mengetahui bagaimana kelayakan teknis pada usaha pengolahan limbah ikan menjadi pupuk organik cair (POC) di Desa Tanah Merah Kecamatan Belitang Madang Raya Kabupaten OKU Timur.

2. Menganalisa potensi tingkat keuntungan pada usaha pengolahan limbah ikan menjadi pupuk organik cair (POC) di Desa Tanah Merah Kecamatan Belitang Madang Raya Kabupaten OKU Timur.

\section{KERANGKA PEMIKIRAN}

\section{A. Tinjauan Pustaka}

\section{Pupuk Organik Cair (POC)}

Menurut Patanga dan Yuliatri (2016), mengatakan bahwa pupuk organik cair dibagi menjadi tiga jenis, antara lain sebagai berikut:

\section{Pupuk Kandang Cair}

Pupuk kandang cair yaitu pupuk cair yang bahan bakunya adalah urine.Pupuk kandang cair mempunyai kelebihan-kelebihan, yakni mengandung unsur hara yang sangat dibutuhkan oleh tanaman, baik untuk pertumbuhan, perkembangan, maupun kesehatan tanaman, seperti unsur $\mathrm{N}$ (Nitrogen) $\mathrm{P}$ (Fosfor) dan $\mathrm{K}$ (Kalium). Unsur (N) digunakan untuk pertumbuhan tunas batang dan daun.
Unsur $(\mathrm{P})$ digunakan untuk pertumbuhan akar buah dan biji. Unsur $(\mathrm{K})$ membentuk ketahanan tanaman terhadap hama dan penyakit.

2. Pupuk Hijau Cair

Pupuk hijau cair yaitu pupuk yang bahan bakunya adalah dari dedaunan hijau atau sampah dapur seperti sisa-sisa sayuran dan ditambah dengan sejumlah bahanbahan serta sejumlah air, sehingga akhir dari proses ini menghasilkan pupuk hijau cair. Kelebihan pupuk ini yaitu waktu yang digunakan untuk membuat pupuk ini lebih singkat dibandingkan dengan membuat pupuk organik padat.

3. Kompos Cair

Kompos cair adalah jenis pupuk organik hasil dari proses fermentasi atau dekomposisi bahan dasar, seperti tumbuhan, sampah dapur dan lain-lain, dengan menambahkan bioaktivator cair dan sejumlah air yang memadai. Akhir proses dari pupuk ini ( \pm 15 hari) akan menghasilkan air sampah yang disebut lindi. Air lindi ini akan dihasilkan secara bertahap dan dalam beberapa hari ditampung dalam wadah tertentu untuk dimanfaatkan sebagai pupuk organik.

\section{B. Model Pendekatan}

Model pendekatan diagramatis yang digunakan dalam penelitian ini adalah sebagai berikut:

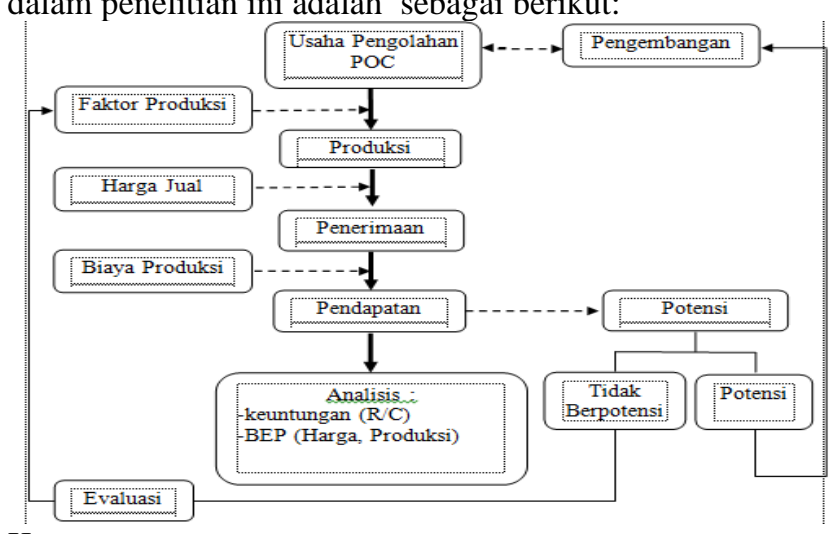

Keterangan :

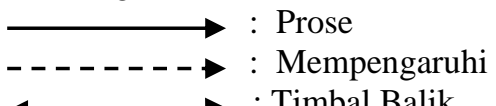

Gambar 1. Model Pendekatan Diagramatis Pemanfaatan Limbah Ikan Menjadi Pupuk Organik Cair

\section{METODOLOGI PENELITIAN}

\section{A. Tempat dan Waktu}

Penelitian ini dilaksanakan di kampus STIPER Belitang Desa Tanah Merah Kecamatan Belitang Madang Raya Kabupaten OKU Timur. Penelitian ini dilaksanakan dengan purposive (sengaja) dengan pertimbangan bahwa di daerah tersebut terdapat usaha untuk pengelolaan limbah tersebut yaitu pengolahan limbah ikan menjadi pupuk organik cair menggunakan alat fermentor. Penelitian ini dilakukan pada bulan Desember 2019 sampai dengan Maret 2020. 


\section{B. Metode Penelitian}

Metode penelitian yang digunakan dalam penelitian adalah metode study kasus, menurut Walgito (2010) menyatakan bahwa study kasus merupakan suatu metode untuk menyelidiki atau mempelajari suatu kejadian mengenai perseorangan atau suatu usaha, yaitu pengelolaan limbah ikan menjadi pupuk organik cair (POC) di Desa Tanah Merah Kecamatan Belitang Madang Raya Kabupaten OKU Timur.

\section{Metode Pengumpulan Data dan Penarikan Contoh}

Data yang dikumpulkan dalam penelitian ini adalah data primer dan data sekunder.Data primer diperoleh dari responden dengan wawancara langsung berdasarkan data kuisioner yang telah disampaikan.Sedangkan data sekunder diperoleh dari lembaga-lembaga yang berkaitan dengan penelitian.

Metode penarikan contoh yang digunakan adalah penarikan contoh sensus terhadap usaha pengelolaan limbah ikan menjadi pupuk organik cair (POC) menggunakan fermentor. Menurut Suryabrata (2005) menyatatakan bahwa, metode sensus adalah sebuah metode dimana semua elemen memiliki kesempatan untuk dijadikan contoh (sampel). Samel yang diambil berjumlah 1 dari 1 populasi.

\section{Metode Pengolahan Data}

1. Untuk mengetahui kelayakan teknis menggunakan metode deskriptif, yaitu sebuah penelitian yang memaparkan suatu karakteristik atau ciri tertentu dari sebuah fenomena atau permasalahan yang terjadi ( Sugiarto, 2017).

2. Untuk menganalisa tingkat keuntungan usaha pengolahan limbah ikan menggunakan metode sebagai berikut:

a). Untuk menghitung besarnya pendapatan dan tingkat keuntungan digunakan rumus sebagai berikut (Soekartawi, 2006): TC $=$ FC + VC

Dimana :

TC (Total Cost) : Biaya Total

FC (Fixed Cost) : Biaya Tetap

VC (Variable Cost) : Biaya Variabel

$$
\mathrm{TR}=\mathrm{P} \times \mathrm{Q}
$$

Dimana :

TR (Total Revenue) : Penerimaan Total

$$
\begin{array}{ll}
\mathrm{P}(\text { Price }) & \text { : Harga } \\
\mathrm{Q} \text { (Quantity) } & \text { : Jumlah Produksi }
\end{array}
$$

Dimana :

$\pi \quad$ : Pendapatan bersih

TR (Total Revenue) : Penerimaan Total

TC (Total Cost) : Biaya Total

$$
\mathrm{R} / \mathrm{C} \text { Ratio }=\frac{T R}{T C}
$$

Dimana :

R/C Ratio : Rasio perbandingan antara penerimaan dan biaya

TC : Total cost / total biaya

TR : Total revenue / total penerimaan

Keterangan :

- Jika nilai $\mathrm{R} / \mathrm{C}>1 \rightarrow$ maka usaha pengolahan limbah ikan menguntungkan.

- Jika nilai $\mathrm{R} / \mathrm{C}=1 \rightarrow$ maka usaha pengolahan limbah ikan mengalami titik impas.
- Jika nilai $\mathrm{R} / \mathrm{C}<1 \rightarrow$ maka usaha pengolahan limbah ikan merugi.

b). BEP harga adalah harga terendah dimana sebuah usaha berada pada titik impas, dengan rumus :

$$
\text { BEP harga }=\frac{T C}{Y}
$$

Dimana :

TC: Total Cost / biaya total (Rp)

$\mathrm{Y}$ : Yield / jumlah produk $(\mathrm{Kg})$

c). BEP Produk adalah produksi terendah dimana sebuah usaha berada pada titik impas, dengan rumus

Dimana :

$$
\mathrm{BEP} \text { produk }=\frac{T C}{P}
$$

TC: Total Cost / biaya total (Rp)

$\mathrm{P}$ : Price / harga

\section{HASIL DAN PEMBAHASAN}

\section{Analisis Keuntungan Usaha Pupuk Organik Cair}

\section{Biaya Tetap (Fixed Cost)}

Biaya tetap yang digunakan dan dikeluarkan oleh pelaku usaha pengolahan limbah ikan menjadi pupuk organik cair di Desa Tanah Merah Kecamatan Belitang Madang Raya Kabupaten OKU Timur meliputi biaya sewa lahan dan penyusutan alat dapat dilihat pada tabel berikut:

Tabel 2. Biaya Tetap Usaha Pengolahan Limbah Ikan Menjadi POC di Desa Tanah Merah Kecamatan Belitang Madang Raya Kabupaten OKU Timur.

\begin{tabular}{cccc}
\multirow{2}{*}{ No } & \multirow{2}{*}{ Uraian } & \multicolumn{2}{c}{ Biaya Tetap } \\
& & $(\mathbf{R p} / \mathbf{P P})$ & $(\mathbf{R p} / \mathbf{B} / \mathbf{n})$ \\
\hline 1. & Biaya Sewa Tempat & 250.000 & 500.000 \\
2. & Biaya Penyusutan Alat & 88.125 & 176.250 \\
\hline & Jumlah & $\mathbf{3 3 8 . 1 2 5}$ & $\mathbf{6 7 6 . 2 5 0}$ \\
\hline
\end{tabular}

Sumber : Olahan Data Primer, 2020.

Kegiatan usaha pengolahan limbah ikan menjadi pupuk organik cair di Desa Tanah Kecamatan Belitang Madang Raya Kabupaten OKU Timur dalam satu kali proses produksi yaitu satu kali dalam dua minggu sehingga dalam satu bulan dilakukan dua kali proses produksi. Berdasarkan pengolahan data primer pada tabel 20 diatas dapat diketahui biaya penyusutan alat tersebut diantaranya yaitu terdiri atas alat fermentor, blender, baskom, ember dan gayung dengan total Rp 88.125/Proses atau Rp 176.250/Bulan. Sedangkan untuk sewa tempat yaitu gedung sebagai tempat usaha adalah sebesar Rp 250.000/Proses atau Rp 500.000/Bulan. Sehingga biaya tetap yang dikeluarkan dalam usaha pengolahan limbah ikan menjadi pupuk organik cair ini adalah sebesar Rp 338.125/Proses atau Rp 676.250/Bulan.

\section{Biaya Variabel (Variable Cost)}

Biaya variabel yaitu biaya yang digunakan dalam usaha pengolahan limbah ikan menjadi pupuk organik cair di Desa Tanah Merah Kecamatan Belitang Madang Raya Kabupaten OKU Timur dan habis dalam satu kali proses produksi. Biaya variable pada usaha pengolahan limbah 
ikan menjadi pupuk organik cair di Desa Tanah Merah Kabupaten Belitang Madang Raya Kabupaten OKU Timur terdiri dari bahan Baku dan tenaga kerja. Adapun besarnya biaya variabel dari usaha pengolahan limbah ikan menjadi pupuk organik cair (POC) dapat dilihat pada tabel berikut:

Tabel 3. Biaya Variabel Usaha Pengolahan Limbah Ikan Menjadi POC di Desa Tanah Merah Kabupaten OKU Timur.

\begin{tabular}{ccrc}
\hline \multirow{2}{*}{ No } & \multirow{2}{*}{ Uraian } & \multicolumn{2}{c}{ Biaya Variabel } \\
& & $(\mathbf{R p} / \mathbf{P P})$ & $(\mathbf{R p} / \mathbf{B} \mathbf{n})$ \\
\hline 1 & Biaya Bahan Baku & 32.611 .200 & 65.122 .400 \\
& & 1.587 .500 & 4.762 .500 \\
\hline \multirow{2}{*}{ Biaya Tenaga Kerja } & Jumlah & $\mathbf{3 4 . 1 9 8 . 7 0 0}$ & $\mathbf{6 9 . 8 8 4 . 9 0 0}$ \\
\hline
\end{tabular}

Sumber : Olahan Data Primer, 2020.

Berdasarkan tabel diatas dapat diketahui bahwa biaya bahan baku terdiri dari limbah ikan dengan harga $\mathrm{Rp}$ $5.000 / \mathrm{Kg}$, air cucian beras Rp 300/Liter, bawang merah Rp $32.000 / \mathrm{kg}$, kecambah Rp 14.000/Kg, EM4 Rp 25.000/Liter, tetes tebu Rp 20.000/Liter, air Rp 100/Liter, Botol dan Stiker Rp 5000/unit dan untuk biaya Listrik. Sedangkan tenaga kerja yang digunakan dalam usaha pengolahan limbah ikan menjadi pupuk organik cair yaitu seperti persiapan bahan baku, pencampuran bahan, pengadukan pertama, pengadukan kedua, dan pengisian botol, sistem upah tenaga kerja yang ada di Kecamatan Belitang Madang Raya yaitu satu hari rata-rata berkisar Rp. 100.000/Orang. Sehingga total biaya produksi pada usaha pengolahan limbah ikan menjadi pupuk organik cair sebesar Rp 34.198.700/Proses atau Rp 69.884.900/Bulan.

\section{Biaya Total (Total Cost)}

Biaya dalam kegiatan usaha dikeluarkan oleh pelaku usaha dengan tujuan untuk menghasilkan pendapatan yang tinggi bagi usaha yang dikerjakan, dengan mengeluarkan biaya maka pelaku usaha mengharapkan pendapatan yang setinggitingginya melalui peningkatan produksi. Biaya yang dikeluarkan oleh pelaku usaha pada usaha pengolahan limbah ikan menjadi POC terdiri dari biaya tetap dan biaya variabel. Dalam penelitian ini yang dikelompokan kedalam biaya tetap diantaranya adalah sewa lahan dan penyusutan alat sedangkan biaya variabel adalah saprodi dan tenaga kerja.

Biaya tetap terdiri dari gedung dan sarana prasarana usaha. Untuk status kepemilikan tempat responden atau pelaku usaha adalah milik sendiri. Harga sewa gedung yang ada di Kecamatan Belitang Madang Raya pertahun Rp. 5.000.000. sarana dan prasarana yang digunakan yaitu seperti alat fermentor, blender, ember, drigen, dan gayung. Umur ekonomis alat-alat tersebut sekitar 3-5 tahun atau 36-60 bulan.

Biaya variabel (biaya tidak tetap) terdiri dari bahan baku dan tenaga kerja. Bahan baku terdiri dari limbah ikan

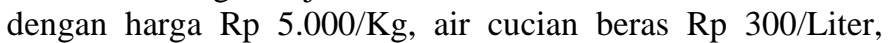
bawang merah Rp 32.000/kg, kecambah Rp 14.000/Kg, EM4 Rp 25.000/Liter, tetes tebu Rp 20.000/Liter, air Rp 100/Liter, Botol dan Stiker Rp 5000/ unit. Sedangkan tenaga kerja yang digunakan dalam usaha pengolahan limbah ikan menjadi pupuk organik cair yaitu seperti persiapan bahan baku, pencampuran bahan, pengadukan pertama, pengadukan kedua, dan pengisian botol, sistem upah tenaga kerja yang ada di
Kecamatan Belitang Madang Raya yaitu satu hari rata-rata berkisar Rp. 100.000/Orang. Rincian biaya produksi pada usaha pengolahan limbah ikan menjadi pupuk organik cair dapat dilihat pada tabel berikut:

Tabel 4. Total Biaya Produksi Usaha Pengolahan Limbah Ikan Menjadi POC.

\begin{tabular}{llcc}
\hline \multirow{2}{*}{ No } & Uraian & \multicolumn{2}{c}{ Total Biaya Produksi } \\
& & $(\mathbf{R p} / \mathbf{P P})$ & $(\mathbf{R p} / \mathbf{B I n})$ \\
\hline 1 & Biaya Tetap & & \\
& & & \\
& • Biaya Sewa Tempat & 250.000 & 500.000 \\
& • Biaya Penyusutan Alat & 88.125 & 176.250 \\
2 & Biaya Variabel & & \\
& • Biaya Sarana Produksi & 32.611 .200 & 65.122 .400 \\
& • Biaya Tenaga Kerja & 1.587 .500 & 4.762 .500 \\
\hline & Jumlah & $\mathbf{3 4 . 5 3 6 . 8 2 5}$ & $\mathbf{7 0 . 5 6 1 . 1 5 0}$ \\
\hline
\end{tabular}

Sumber : Olahan Data Primer, 2020.

Berdasarkan tabel diatas diketahui bahwa biaya tetap terdiri dari sewa lahan sebesar Rp 250.000/ Proses atau R 500.000/Bulan dan biaya penyusutan alat sebesar $\mathrm{Rp}$ 88.125/Proses atau Rp 176.250/Bulan, sedangkan biaya variabel terdiri dari bahan baku sebesar Rp 32.611.200/Proses atau Rp 65.122.400/Bulan dan tenaga kerja sebesar Rp 1.587.500/Proses atau Rp 4.762.500/Bulan sehingga biaya total dalam usaha pengolahan limbah ikan menjadi pupuk organik cair yaitu sebesar Rp 34.536.825/Proses atau Rp 70.561.150/Bulan.

Untuk skala petani jumlah tersebut tergolong besar. Biaya begitu besar dikarnakan pada biaya sarana prouksi memerlukan pengadaan botol dan stiker yang cukup banyak untuk proses pacing. Jumlah botol dan stiket yang yang digunakan dalam satu kali proses produksi adalah sebanyak masing-masing 6000 buah dengan harga Rp 5000. Akan tetapi petani yang ingin melakukan proses usaha ini dapat menyiasati dengan menggunakan botol bekas air mineral atau drigen untuk pemakaian sendiri.

\section{Produksi, Harga, Penerimaan, dan Pendapatan}

Penerimaan usaha pengolahan limbah ikan menjadi pupuk organik cair dapat diartikan sebagai besaran keseluruhan hasil produksi yang diperoleh dari hasil produksi yang diperoleh dari hasil produksi usaha pengolahan limbah ikan menjadi pupuk organik cair dan diberikan dengan harga yang berlaku saat ini didaerah yang bersangkutan. Selanjutnya didalam penerimaan agribisnis tidak terlepas dari harga dan produk. Sebuah usaha akan menghasilkan produk jika harga memadai. Hal ini sesuai dengan pendapatan bahwa, harga salah satu produk berpengaruh dalam pemasaran hasil pertanian (Sjarkowi dan Sufri, 2004).

Pendapatan merupakan hasil berupa penerimaan yang diterima oleh pelaku usaha setelah dikurangi total biaya produksi yang dikeluarkan dalam usaha pengolah limbah ikan menjadi pupuk organik cair. Nilai pendapatan ini merupakan hasil bersih yang diperoleh selama proses produksi. Adapun produksi, harga, penerimaan dan 
pendapatan yang diterima oleh pelaku usaha pengolahan limbah ikan menjadi pupuk organik cair di Desa Tanah Merah Kecamatan Belitang Madang Raya Kabupaten OKU Timur dapat dilihat pada tabel berikut:

Tabel 5. Produksi, Harga, Penerimaan Dan Pendapatan POC dari Limbah Ikan.

\begin{tabular}{rlrrr} 
No & Uraian & Satuan & \multicolumn{1}{l}{ PP } & \multicolumn{1}{l}{ Bulan } \\
\hline 1 & Produksi & Btl & 5.940 & 11.880 \\
2 & Harga Jual & Rp/Btl & 40.000 & \\
3 & Penerimaan & Rp & 237.600 .000 & 475.200 .000 \\
4 & Biaya Produksi & Rp & 34.536 .825 & 69.073 .650 \\
5 & Pendapatan & Rp & 203.063 .175 & 406.126 .350 \\
\hline
\end{tabular}

Sumber : Olahan Data Primer, 2020.

Berdasarkan tabel diatas diketahui bahwa biaya total produksi pengolahan limbah ikan menjadi pupuk organik cair sebesar Rp 34.536.825/Proses atau Rp 69.073.650/Bulan. Produksi pengolahan limbah ikan menjadi pupuk organik cair dalam satu kali proses produksi memperoleh 5.940 Botol/PP dengan harga Rp 40.000/Botol, sehingga memperoleh penerimaan sebesar Rp 237.600.000/Proses atau Rp 475.200.000/Bulan dan pendapatan sebesar Rp. 203.063.175 /Proses atau Rp 406.126.350/Bulan.

Besarnya pendapatan yang diperoleh oleh pelaku usaha dikarenakan banyaknya hasil produksi yaitu mencapai \pm 6000 botol dan harga yang tinggi sebesar Rp 40.000, sedangkan untuk biaya bahan baku sangat terjangkau yaitu hanya $\mathrm{Rp}$ $5.000 / \mathrm{kg}$ dan mudah didapatkan. Jika dilihat dari besar pendapatan yang diperoleh usaha pengolahan limbah ikan menjadi pupuk organik cair (POC) bisa dijadikan sebagai usaha utama bagi pelaku usaha, karena hasil penjualanya menurut peneliti sudah mampu untuk memenuhi kebutuhan keluarga.

\section{R/C Ratio}

Untuk mengetahui tingkat keuntungan usaha pengolahan limbah ikan menjadi pupuk organik cair diperoleh dari perbandingan antara penerimaan dan biaya produksi yang dikeluarkan (Soekartawi, 2002). Untuk mengukur efisiensi suatu usahatani digunakan analisis R/C Ratio (Return Cost Ratio), dapat dilihat pada tabel berikut:

Tabel 6. Nilai Keuntungan Usaha Pengolahan Limbah Ikan Menjadi Pupuk Organik Cair di Desa Tanah Merah Kecamatan Belitang Madanga Raya Kabupaten OKU Timur, 2019.

\begin{tabular}{cccc}
\hline No & $\begin{array}{c}\text { Penerimaan } \\
(\mathrm{Rp} / \mathrm{PP})\end{array}$ & $\begin{array}{c}\text { Biaya Produksi } \\
(\mathrm{Rp} / \mathrm{PP})\end{array}$ & RC Ratio \\
\hline 1. & 237.600 .000 & 34.536 .825 & 6,88 \\
\hline
\end{tabular}

Sumber : Olahan Data Primer, 2020.

Dari tabel diatas dapat diketahui nilai R/C Ratio pada usaha pengolahan limbah ikan menjadi pupuk organik cair sebesar 6,88. Artinya bahwa setiap Rp. 1 yang dikeluarkan untuk usaha pengolahan limbah ikan menjadi pupuk organik cair menghasilkan penerimaan sebesar Rp 6,88. Nilai R/C > 1, menunjukan bahwa usaha pengolahan limbah ikan menjadi pupuk organik cair di Desa Tanah Merah Kecamatan Belitang Madang Raya Kabupaten OKU Timur menguntungkan.

Keuntungan dari usaha pengolahan limbah ikan menjadi pupuk organik cair (POC) di Desa Tanah Merah Kecamatan Belitang Madang Raya Kabupaten OKU Timur ini hampir mencapai angka 7 kali lipat dari modal yang dikeluarkan. Hal tersebut terjadi karena penerimaan yang begitu besar sedangkan biaya produksinya rendah, sehingga keuntungan dari pengolahan limbah ikan menjadi pupuk organik cair (POC) ini cukup besar.

\section{BEP (Break Event Point)}

BEP (Break Event Point) yang ada pada usaha pengolahan limbah ikan menjadi pupuk organik cair di Desa Tanah Merah Kecamatan Belitang Madang Raya meliputi BEP Harga, dan BEP Produksi.

\section{a. BEP Harga}

BEP (Break Event Point) Harga dari usaha pengolahan limbah ikan menjadi pupuk organik cair di Desa Tanah Merah Kecamatan Belitang Madang Raya Kabupaten OKU Timur dapat di lihat pada tabel berikut:

Tabel 7. BEP Harga Usaha Pengolahan Limbah Ikan Menjadi Pupuk Organik Cair di Desa Tanah Merah Kecamatan Belitang Madang Raya Kabupaten OKU Timur, 2019.

\begin{tabular}{cccc}
\hline No & $\begin{array}{c}\text { Biaya Total } \\
(\text { Rp/PP })\end{array}$ & $\begin{array}{c}\text { Produksi } \\
(\text { Btt/PP })\end{array}$ & BEP Harga \\
\hline 1 & 34.536 .825 & 5.940 & 5.814
\end{tabular}

Sumber : Olahan Data Primer, 2020

BEP harga pada usaha pengolahan limbah ikan menjadi pupuk organik cair di Desa Tanah Merah Kecamatan Belitang Madang Raya Kabupaten OKU Timur diperoleh sebesar Rp 5.814/Botol. Yang berarti jika pelaku usaha pengolahan limbah ikan menjadi pupuk organik cair menjual pupuk organik cair dengan harga Rp 5.814/Botol maka pelaku usaha tidak memperoleh keuntungan atau kerugian (impas), jika pelaku usaha menjual di bawah harga Rp 5.814/Botol maka akan mengalami kerugian dan jika pelaku usaha menjual produknya di atas harga Rp 5.814/Botol maka pelaku usaha akan memperoleh keuntungan.

Jika dilihat dari besarnya nilai BEP harganya yaitu Rp 5.814/Botol usaha pengolahan limbah ikan menjadi pupuk organik cair (POC) di Desa Tanah Merah Kecamatan Belitang Madang Raya Kabuaten OKU Timur ini sangat rendah dari harga yang ditetapkan oleh pelaku usaha yaitu sebesar Rp 40.000/Botol. Artinya selisih harga yang ditetapkan dengan nilai BEP yang dipperoleh adalah sebesar Rp 34.186. Sehingga Pelaku usaha dapat memeroleh keuntungan yang tinggi yaitu sebesar Rp 203.063.175/Proses.

b. BEP Produksi

BEP Produksi dari usaha pengolahan limbah ikan menjadi pupuk organik cair di Desa Tanah Merah Kecamatan Belitang Madang Raya Kabupaten OKU Timur dapat dilihat pada tabel berikut:

Tabel 8. BEP Produksi Usaha Pengolahan Limbah Ikan Menjadi Pupuk Organik Cair di Desa Tanah 
Merah Kecamatan Belitang Madang Raya Kabupaten OKU Timur, 2019.

\begin{tabular}{cccc}
\hline No & $\begin{array}{c}\text { Biaya Total } \\
(\text { Rp/PP) }\end{array}$ & $\begin{array}{c}\text { Harga } \\
(\text { Rp/Btl })\end{array}$ & BEP Produksi \\
\hline 1 & 34.536 .825 & 40.000 & 863 \\
Sumber : Olahan Data Primer, 2020. &
\end{tabular}

BEP produki dari usaha pengolahan limbah ikan menjadi pupuk organik cair di Desa Tanah Merah Kecamatan Belitang Madang Raya Kabupaten OKU Timur diperoleh 863/Botol. Yang berarti jika pelaku usaha pengolahan limbah ikan menjadi pupuk organik cair memproduksi pupuk organik cair sebanyak 863 Botol/Proses maka pelaku usaha tidak memperoleh keuntungan atau kerugian (impas). Jika dilihat dari besarnya nilai BEP produknya yaitu 863 Botol usaha pengolahan limbah ikan menjadi pupuk organik cair (POC) di Desa Tanah Merah Kecamatan Belitang Madang Raya Kabuaten OKU Timur ini memiliki selisih sebanyak 5.077 Botol.

Dari hasil BEP harga dan produksi diatas maka dapat digambar kurva sebagai berikut:

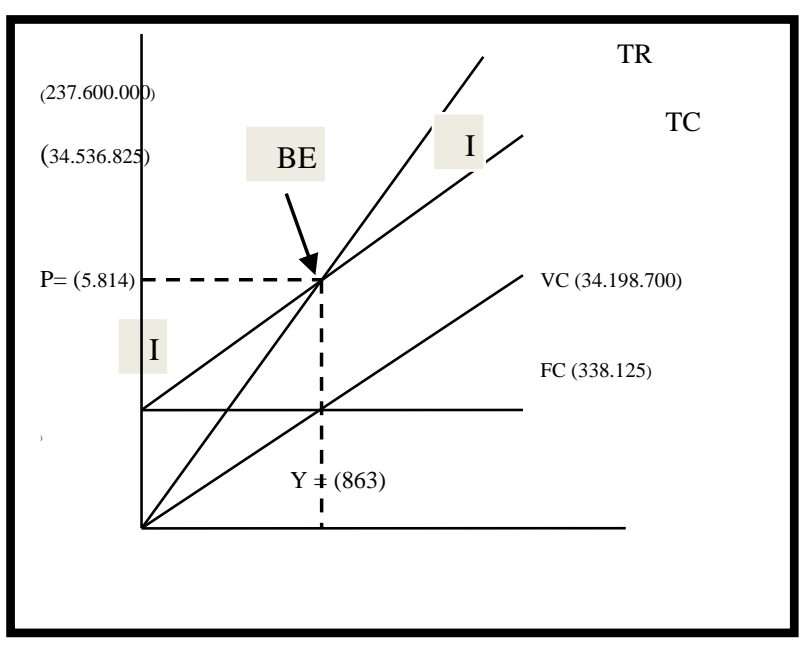

Gambar 2. Kurva BEP Analisis Pemanfaatan Limbah Ikan Menjadi POC

Berdasarkan grafik BEP diatas, dapat diketaui bahwa produksi pupuk organik cair yang dihasilkan berada diatas garis BEP atau lebih besar dari pada nilai BEP. Dari grafik di atas juga dapat diketahui bahwa hasil produksi pupuk organik cair dari limbah ikan ini berada zona II atau berada ada zona laba, yang menunjukkan bahwa usaha pengolahan pupuk organik cair dari limbah ikan ini menguntungkan. Berdasarkan perhitungan BEP harga dan BEP produksi diatas dapat disimpulkan bahwa usaha pengolahan limbah ikan menjadi puppuk organik cair (POC) di Desa Tanah Merah Kecamatan Belitang Madang Raya Kabupaten OKU Timur menguntungkan dan layak secara finansial.

\section{KESIMPULAN DAN SARAN}

\section{A. Kesimpulan}

Berdasarkan hasil penelitian yang telah dilakukan maka dapat ditarik kesimpulan, sebagai berikut :
1. Usaha pengolahan limbah ikan menjadi pupuk organik cair di Desa Tanah Merah Kecamatan Belitang Madang Raya Kabupaten OKU Timur layak secara teknis.

2. Usaha pengolahan limbah ikan menjadi pupuk organik cair di Desa Tanah Merah Kecamatan Belitang Madang Raya Kabupaten OKU Timur menguntungkan dengan indikator indikatornya adalah R/C Rasio sebesar 6,88 BEP Harga sebesar Rp 5.814/Botol, BEP produksi sebesar 10/Botol.

\section{B. Saran}

Berdasarkan penelitian yang telah dilakukan pada usaha pengolahan limbah ikan menjadi pupuk organik cair di Desa Tanah Merah Kecamatan Belitang Madang Raya Kabupaten OKU Timur, peneliti menyarankan agar pelaku usaha senang tiasa untuk tetap menjaga, memperhatikan dan meningkatkan kualitas produk.

\section{DAFTAR PUSTAKA}

Hadisuwito, S. 2007. Membuat Pupuk Kompos Cair. PT. Agromedia Pustaka. Jakarta.

Hapsari, N. dan Welasi, T. 2013. Pemanfaatan Limbah Ikan Menjadi Pupuk Organik. Jurnal Teknik Lingkungan. 2(1). 1-6.

Hartati. 2010. Pengolahan Limbah Daun Kering Sebagai Briket Untuk Alternatif Pengganti Bahan Bakar Minyak. Politeknik Negeri Padang. Padang.

Indrian. 2013. Studi Pengaruh Penambahan Limbah Ikan Pada Proses Pembuatan Pupuk Cair Dari Urin Sapi Terhadap Kandungan Unsur Hara Makro (CNPK) Jurnal Teknik Lingkungan. 2(2).1-16.

Mazaya, M. Susatyo, E.B. dan Prasetya, A.T. 2013. Pemanfaatan Tulang Ikan Kakap Untuk Meningkatkan Kadar Fosfor Pupuk Cair Limbah. 2(1).

Petanga, A dan Yuliarti, N. 2016. Pembuatan, Aplikasi, dan Bisnis Pupuk Organik dari Limbah Pertanian, Peternakan, dan Rumah Tangga. PT Gramedia pustaka umum. Jakarta.

Prihandarini, R. 2014. Manajemen Sampah, Daur Ulang Sampah Menjadi Pupuk Organik. PerPod. Jakarta.

Resmawati. 2012 Pengaruh Pemberian Pupuk Cair Limbah Ikan Lemuru (Sardinella sp.) Terhadap Kepadatan Populasi Spirulina platensis. Universitas Airlangga. Surabaya.

Sjarkowi, F dan Marwan, S. 2004. Manajemen Agribisnis. CV Baldad Grafiti Press. Palembang.

Sjarkowi, F. 2010. Manajemen Pembangunan Agribisnis. Palembang. CV Baldad Grafiti Press. Palembang.

Suharto, I. 2011. Limbah Kimia dalam Pencemaran Air dan Udara. CV. Andi Offset. Yogyakarta.

Sutedjo, M. 2010. Pupuk Dan Cara Pemupukan. Rineka Cipta. Jakarta. 